\title{
CT abnormalities of the pituitary in hyperprolactinaemic women with normal or equivocal sellae radiologically
}

\author{
R T JUNG, M C WHITE, N B BOWLEY, G BYDDER, K MASHITER, G F JOPLIN
}

\begin{abstract}
Sixteen young women with hyperprolactinaemia and normal or equivocal sella in radiographs underwent computed tomography using a Siemens Somatom II. In all but one case an abnormality was found. The sella was full in seven and partially empty in nine. A tumour was visible in six of the full and in four of the partially empty sellae. All but one of the 10 tumours was unilateral, and in seven the pituitary stalk was deviated away from the tumour. After administration of intravenous contrast (Urografin) four tumours showed diffuse enhancement, four ring enhancement, and two enhanced less than adjacent normal pituitary tissue. Two of the tumours have been subsequently shown histologically to be prolactinomas. Prolactin response to thyrotrophin-releasing hormone predicted a tumour in seven out of eight with visible tumours but also in three out of four without visible tumours; using metoclopramide, a tumour was predicted in six out of seven with tumours, but again in three out of four without visible tumours. Such results question the value of dynamic tests for the discrimination of tumours.

We conclude that practically all women with sustained hyperprolactinaemia and a normal or equivocal sella radiologically have pituitary disease.
\end{abstract}

\section{Introduction}

In those women with hyperprolactinaemia who have a pituitary fossa with normal or equivocal appearance in conventional radiographs it is difficult to predict the outcome, especially in those who wish to become pregnant. Up to $5 \%$ of such women may develop visual abnormalities in pregnancy due to pituitary expansion but there is no sure way of predicting those likely to have this complication. ${ }^{12}$ Until recently CT scanners have not been accurate enough to define morphological changes within the sella apart from showing a largely empty sella. ${ }^{3}$ The advent of fourth-generation CT scanners with computerised two-dimensional reconstruction has produced a major advance in the definition of the contents of the sella. We undertook CT scans (using a Siemens Somatom II scanner) in 16 hyperprolactinaemic women with a normal or equivocal fossa in conventional radiographs and compared the findings with those of endocrine dynamic and function tests.

\footnotetext{
Departments of Medicine and Radiology, Royal Postgraduate Medical School, Hammersmith Hospital, London W12 0HS

R T JUNG, MD, MRCP, senior registrar in endocrinology (now: consultant physician, Ninewells Hospital and Medical School, Dundee)

$M$ C WHITE, MRCP, honorary senior registrar in endocrinology

N B BOWLEY, FRCR, senior lecturer in radiology

G BYDDER, MRCP, senior research fellow

K MASHITER, PHD, endocrinologist

G F JOPLIN, PHD, FRCP, reader in clinical endocrinology and honorary consultant physician
}

\section{Patients and methods}

A consecutive series of 16 women attending our endocrine clinic for long-term follow-up of sustained hyperprolactinaemia who had normal or equivocal pituitary fossa appearance on radiographs were studied. They always had prolactin concentrations greater than $25 \mu \mathrm{g} / \mathrm{l}$ : all had complained of oligomenorrhoea or amenorrhoea, galactorrhoea, or both. Table I shows clinical details; prolactin concentrations are shown as the mean of all available values at the time of computed tomography. None of the women was taking drugs or oral contraceptives, except one (case 11) who was taking $200 \mu \mathrm{g}$ thyroxine for primary hypothyroidism diagnosed in 1978. All had had pituitary radiographs previously judged to be normal or suspicious of tumour (MacErlean and Doyle categories 3, 4, or 5) 4 based on coned views (lateral, anteroposterior, and Towne's projections) and lateral polytome hypocycloidal tomography at $3 \mathrm{~mm}$ cuts.

A Siemens Somatom II scanner was used. The plane of section was minus $10^{\circ}$ to the canthomeatal baseline, and $2 \mathrm{~mm}$ sections spaced back to back were obtained before and after administration of intravenous contrast (Urografin). Where possible, coronal sections were also obtained. Two-dimensional sagittal reconstructions were made, and where coronal section could not be obtained (because of dental fillings) coronal reconstructions were also made. The radiographs of the fossae and CT scans were assessed independently by GB and NBB.

To test pituitary function insulin tolerance (after administration of 0.15 units insulin $/ \mathrm{kg}$ ) and response to gonadotrophin-releasing hormone (using $100 \mu \mathrm{g}$ ) were measured (these tests were performed together); response to thyrotrophin-releasing hormone $(200 \mu \mathrm{g})$ was assessed separately. ${ }^{5}$ Eleven of the patients also had their serum prolactin measured in response to $10 \mathrm{mg}$ of metoclopramide (maxolon) intravenously. Prolactin, growth hormone, thyroid-stimulating hormone, luteinising hormone, follicle-stimulating hormone, thyroxine (T4), and triiodothyronine (T3) were measured by radioimmunoassay, and cortisol by a competitive protein binding method; the methodology, sensitivities, and coefficients of variations of our assays have been published elsewhere. ${ }^{6}$

\section{Results}

\section{FINDINGS IN RADIOGRAPH}

In four cases the pituitary fossa appeared normal (category 5), in another four the sella appeared to show a normal anatomical variance in shape (category 4), whereas in the other eight the sellae were slightly suspicious of containing a tumour (category 3 ) in having either a slight slope of the fossa floor $(<2 \mathrm{~mm})$ on the anteroposterior projection or a slight thinning of the fossa wall (table I).

\section{FINDINGS ON CT SCAN}

In all but one case, some abnormality was found on CT scans. Seven of the sellae were full and nine partially empty (table I).

Full sellae-A tumour was clearly visible in six of the seven full sellae. It was one-sided in five (four on the left), and occupied the whole sella in another patient (case 7) with a suprasellar extension (fig 1). All six full sellae with an identifiable tumour had a convex upper surface shown in coronal cuts, which is not a regular feature of a normal pituitary. The full fossa with no visible tumour (case 2) showed bridging between the anterior and posterior clinoids. This patient had a high prolactin concentration $(166 \mu \mathrm{g} / \mathrm{l})$ despite the apparent absence of an identifiable tumour and had had an uneventful pregnancy induced with bromocriptine. Two of these six tumours showed diffuse enhancement, three showed ring enhancement, and one enhanced less than the adjacent normal pituitary tissue. The pituitary stalk was clearly identifiable in all of the full 
sellae and showed up enhanced at the upper, posterior part of the fossa abutting the dorsum. Four of the five unilateral tumours showed deviation of the stalk away from the tumour; this deviation was a useful marker for the position of the normal pituitary tissue, which can also enhance to a slight degree (fig 2). One of the patients (case 4) with a ring-enhanced abnormality underwent needle pituitary biopsy during yttrium- 90 selective implantation and a prolactinoma was proved histologically; in this patient the hyperprolactinaemia was relieved and menstruation resumed. Another with ring enhancement (case 5) also showed a fall in prolactin after a selective yttrium-90 implant.

Partially empty sellae-A tumour was visible in four of the nine cases with a partially empty sella. Each tumour was unilateral, three on the left side. Three showed diffuse enhancement, one enhanced less than adjacent normal pituitary tissue, and none showed ring enhancement. The pituitary stalk was visualised in all nine cases and was central in those five sellae where a tumour could not be identified. In three out of the four patients with unilateral tumours (cases 8, 11, and 12) the stalk was deviated away from the tumour. In one such patient (case 12) the enhanced tumour was separated by a cleft of cerebrospinal fluid from the normal pituitary tissue, which could be identified only by the position of the stalk. This tumour was histologically confirmed at selective removal by transphenoidal surgery; her hyperprolactinaemia and galactorrhoea were cured and periods resumed, yet pituitary function was preserved clinically and on endocrine testing.

\section{RESULTS OF ENDOCRINE TESTS}

Serum basal prolactin concentrations (table I) did not distinguish the full from the empty sellae, or those with identifiable tumour from those without.

If a prolactinoma is indicated by a prolactin rise after thyrotrophinreleasing hormone of less than $100 \%$ above the basal value then the test correctly identified a tumour in seven of the eight patients tested who had a tumour visible on CT scan. There were, however, three false-positives in the four tested with no tumour visible. If a similar prolactin response to metoclopramide is used as an indication of a tumour then this test correctly identified six of the seven patients tested with a tumour but there were three false-positives in those four tested with no tumour visible on CT.

None of the patients in this series showed clinical hypopituitarism. Out of the 10 (table II) who underwent tests for reserve of pituitary function, only three had mild deficits in response of growth hormone, cortisol, or both to insulin hypoglycaemia (cases 10,13, and 15) and only one (case 9) had abnormally low thyroid-stimulating hormone response to thyrotrophin-releasing hormone (though this patient had normal serum T4 and T3 concentrations) and also a reduced folliclestimulating hormone response to gonadotrophin-releasing hormone. All these four patients with mild defects in reserve function had partially empty sellae, three with no visible tumour. All 14 patients with measurements of serum $\mathrm{T} 3$ and $\mathrm{T} 4$, including case 11 , receiving thyroxine treatment, had normal values.

TABLE II-Basal serum thyroxine (T4) and hormone responses to tests for pituitary reserve in those with full and empty sellae. Results are numbers of patients tested and, except where indicated, are normal

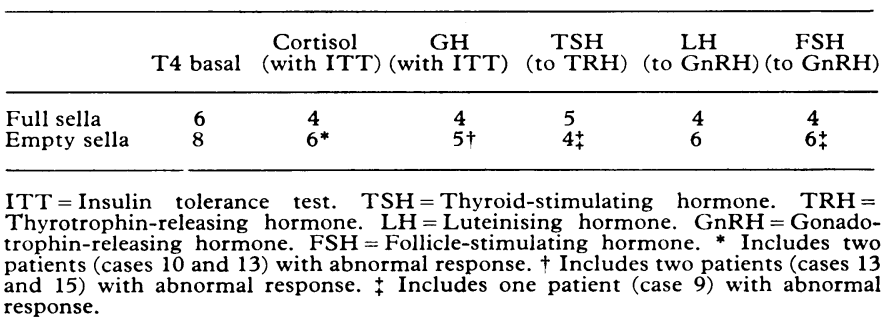
response.

TABLE I-Clinical details on the 16 hyperprolactinaemic women with normal or suspicious sellae on conventional radiology

\begin{tabular}{|c|c|c|c|c|c|c|c|c|c|c|c|c|}
\hline \multirow{3}{*}{$\begin{array}{l}\text { Case } \\
\text { No }\end{array}$} & \multirow{3}{*}{$\begin{array}{l}\text { Age } \\
\text { (yrs) }\end{array}$} & \multirow{2}{*}{\multicolumn{2}{|c|}{ Onset (age in yrs) }} & \multirow{3}{*}{$\begin{array}{c}\text { Basal } \\
\text { prolactin } \\
(\mu \mathrm{g} / 1) \\
(\text { normal }<25)\end{array}$} & \multirow{2}{*}{\multicolumn{2}{|c|}{$\begin{array}{l}\text { Percentage rise }(+) \\
\text { or fall }(-) \text { of } \\
\text { prolactin with }\end{array}$}} & \multirow{3}{*}{$\begin{array}{c}\text { Category } \\
\text { of sella on } \\
x \text {-ray* }\end{array}$} & \multicolumn{4}{|c|}{ CT findings } & \multirow[b]{3}{*}{ Clinical details of interest } \\
\hline & & & & & & & & \multirow[b]{2}{*}{ Sella } & \multicolumn{2}{|c|}{ Tumour } & \multirow[b]{2}{*}{ Stalk } & \\
\hline & & $\begin{array}{l}\text { amenorrhoea } \\
\text { amomenorrnoea }\end{array}$ & Galactorrhoea & & $\mathrm{TRH}$ & Maxolon & & & Feature & Position & & \\
\hline 1 & 21 & 19 & 14 & 100 & -10 & +22 & 5 & Full & Enhanced & $\begin{array}{l}\text { Left- } \\
\text { sided }\end{array}$ & Central & \\
\hline 2 & 21 & 19 & 20 & 166 & +41 & & 4 & Full $\dagger$ & None seen & & Central & $\begin{array}{l}\text { One uneventful preg- } \\
\text { nancy induced with } \\
\text { bromocriptine }\end{array}$ \\
\hline 3 & 39 & 36 & 38 & 100 & & +40 & 4 & Full & $\begin{array}{l}\text { Subnormally } \\
\text { enhanced }\end{array}$ & $\begin{array}{l}\text { Left- } \\
\text { sided }\end{array}$ & $\begin{array}{l}\text { Deviated to } \\
\text { right }\end{array}$ & $\begin{array}{l}\text { One uneventful pregnancy } \\
\text { induced with } \\
\text { clomiphene }\end{array}$ \\
\hline 4 & 28 & 17 & 20 & 151 & +4 & +49 & 4 & Full & $\begin{array}{l}\text { Ring en- } \\
\text { hanced } \\
\text { round } \\
\text { unen- } \\
\text { hanced } \\
\text { core }\end{array}$ & $\begin{array}{l}\text { Left- } \\
\text { sided }\end{array}$ & $\begin{array}{l}\text { Deviated to } \\
\text { right }\end{array}$ & $\begin{array}{l}\text { Prolactinoma proved on } \\
\text { biopsy }{ }^{\circ} \mathrm{Y} \text {-selective } \\
\text { implant }\end{array}$ \\
\hline 5 & 28 & 18 & 27 & 40 & -7 & +26 & 3 & Full & $\begin{array}{l}\text { Ring } \\
\text { enhanced } \\
\text { round } \\
\text { unenhanced } \\
\text { core }\end{array}$ & $\begin{array}{l}\text { Left- } \\
\text { sided }\end{array}$ & $\begin{array}{l}\text { Deviated to } \\
\text { right }\end{array}$ & ${ }^{\circ} \mathrm{Y}$-selective implant \\
\hline 6 & 41 & Periods regular & 22 & 42 & +1286 & +1218 & 4 & Full & $\begin{array}{l}\text { Ring } \\
\text { enhanced } \\
\text { round } \\
\text { unenhanced } \\
\text { core }\end{array}$ & $\begin{array}{l}\text { Right- } \\
\text { sided }\end{array}$ & $\begin{array}{c}\text { Deviated to } \\
\text { left }\end{array}$ & $\begin{array}{l}\text { One spontaneous } \\
\text { uneventful pregnancy }\end{array}$ \\
\hline $\begin{array}{l}7 \\
8\end{array}$ & $\begin{array}{l}22 \\
34\end{array}$ & $\begin{array}{l}18 \\
24\end{array}$ & $\begin{array}{l}18 \\
24\end{array}$ & $\begin{array}{r}165 \\
89\end{array}$ & $\begin{array}{r}+9 \\
-57\end{array}$ & +31 & $\begin{array}{l}5 \\
3\end{array}$ & $\begin{array}{l}\text { Full } \\
\text { Partially } \\
\text { empty }\end{array}$ & $\begin{array}{l}\text { Enhanced } \\
\text { Enhanced }\end{array}$ & $\begin{array}{l}\text { Overall } \\
\text { Right- } \\
\text { sided }\end{array}$ & $\begin{array}{l}\text { Central } \\
\text { Deviated } \\
\text { to left }\end{array}$ & $\begin{array}{l}\text { Two pregnancies, } \\
\text { associated with } \\
\text { diabetes insipidus }\end{array}$ \\
\hline 9 & 33 & 31 & 31 & 172 & +7 & +5 & 3 & $\begin{array}{l}\text { Partially } \\
\text { empty } \S\end{array}$ & Enhanced & $\begin{array}{l}\text { Left- } \\
\text { sided }\end{array}$ & Central & $\begin{array}{l}\text { Miscarriage after } \\
\text { pregnancy induced } \\
\text { with bromocriptine }\end{array}$ \\
\hline 10 & 30 & Periods regular & 29 & 28 & +618 & & 3 & $\begin{array}{l}\text { Partially } \\
\text { empty } \S\end{array}$ & None seen & & Central & $\begin{array}{l}\text { Two pregnancies before } \\
\text { galactorrhoea } \\
\text { developed }\end{array}$ \\
\hline 11 & 36 & Periods regular & 34 & 130 & & & 3 & $\begin{array}{l}\text { Partially } \\
\text { empty }\end{array}$ & Enhanced & $\begin{array}{l}\text { Left- } \\
\text { sided }\end{array}$ & $\begin{array}{l}\text { Deviated to } \\
\text { right }\end{array}$ & $\begin{array}{l}\text { Taking thyroxine for } 1^{\circ} \\
\text { hypothyroidism }\end{array}$ \\
\hline 12 & 27 & 24 & 20 & 71 & +32 & +55 & 5 & $\begin{array}{l}\text { Partially } \\
\text { empty } \S\end{array}$ & $\begin{array}{l}\text { Subnormally } \\
\text { unenhanced }\end{array}$ & $\begin{array}{l}\text { Left- } \\
\text { sided }\end{array}$ & $\begin{array}{l}\text { Deviated to } \\
\text { right }\end{array}$ & $\begin{array}{l}\text { Operative removal of } \\
\text { tumour, proved } \\
\text { histologically }\end{array}$ \\
\hline 13 & 35 & 32 & Nil & 100 & +31 & +58 & 5 & $\begin{array}{l}\text { Partially } \\
\text { empty } \S\end{array}$ & None seen & & Central & \\
\hline 14 & 26 & 19 & 19 & 95 & & +173 & 3 & $\begin{array}{l}\text { Partially } \\
\text { empty }\end{array}$ & None seen & & Central & $\begin{array}{l}\text { Termination of preg- } \\
\text { nancy on social grounds }\end{array}$ \\
\hline 15 & 29 & 13 & 14 & 70 & +28 & +69 & 3 & $\begin{array}{c}\text { Partially } \\
\text { empty }\end{array}$ & None seen & & Central & \\
\hline 16 & 35 & 33 & 33 & 42 & & & 3 & $\begin{array}{r}\text { Partially } \\
\text { empty } \S\end{array}$ & None seen & & Central & $\begin{array}{l}\text { Termination of preg- } \\
\text { nancy on social grounds }\end{array}$ \\
\hline
\end{tabular}

TRH $=$ Thyrotrophin-releasing hormone. * Categories of MacErlean and Doyle (ref 4). 


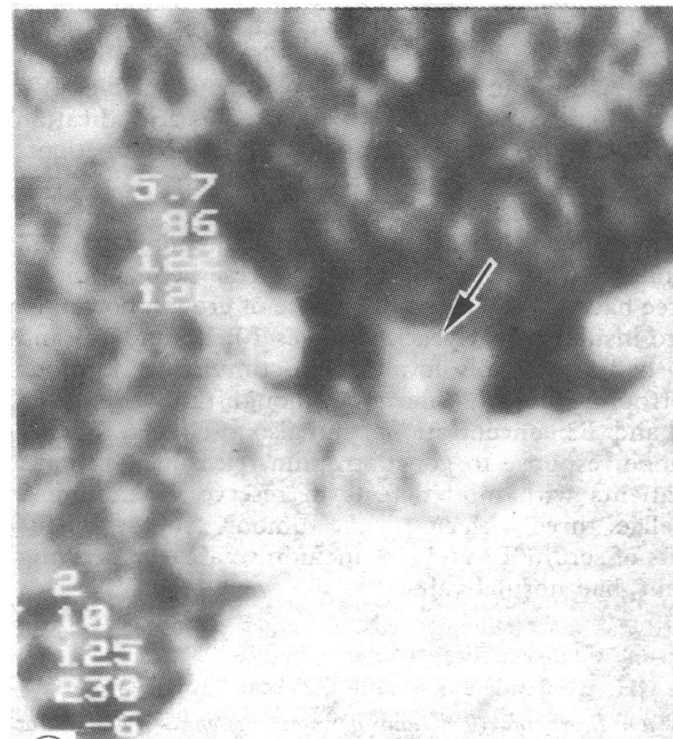

(a)

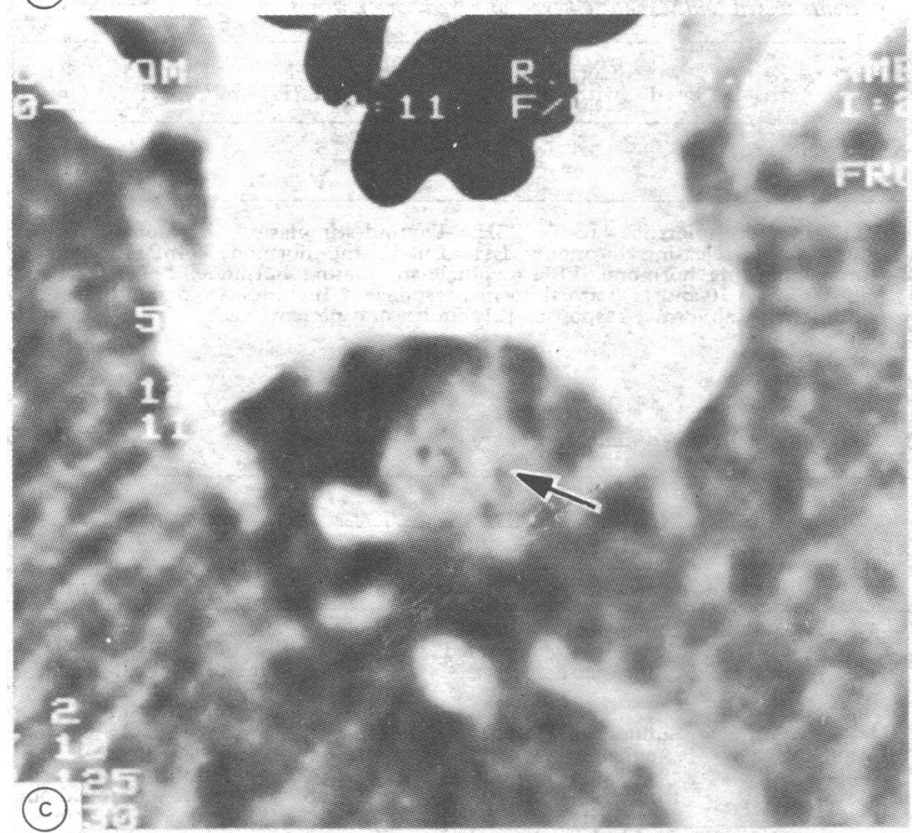

FIG 1-Case 7. CT scans. (A) Enhanced section showing $4 \mathrm{~mm}$ suprasellar extension (arrow), mainly right-sided with slight $(<2 \mathrm{~mm})$ dip of cerebrospinal fluid into sella on left side. (B) More caudal coronal section showing stalk displaced (arrow) to left by suprasellar extension (arrow). (C) Horizontal section showing mainly right-sided suprasellar extension (arrow) with dip of cerebrospinal fluid into sella on left side.

\section{Discussion}

Our most important finding was that the pituitary contents showed some abnormality on CT scans in all but one of the 16 hyperprolactinaemic women with a pituitary fossa that was radiologically either normal or just suspicious of abnormality. This was made possible by the ability of the fourth-generation CT scanner to define accurately the stalk and contents of the pituitary fossa, and to distinguish small tumours from normal pituitary tissue. In some the tumour showed ring enhancement and thus could be clearly defined. In others there was differential enhancement between one part of the pituitary and another; in such cases it was necessary to define the position of the stalk to determine that part which was tumour. In all 16 cases we were able to localise the pituitary stalk, for it enhanced to a slight degree in all patients and was always found posteriorly
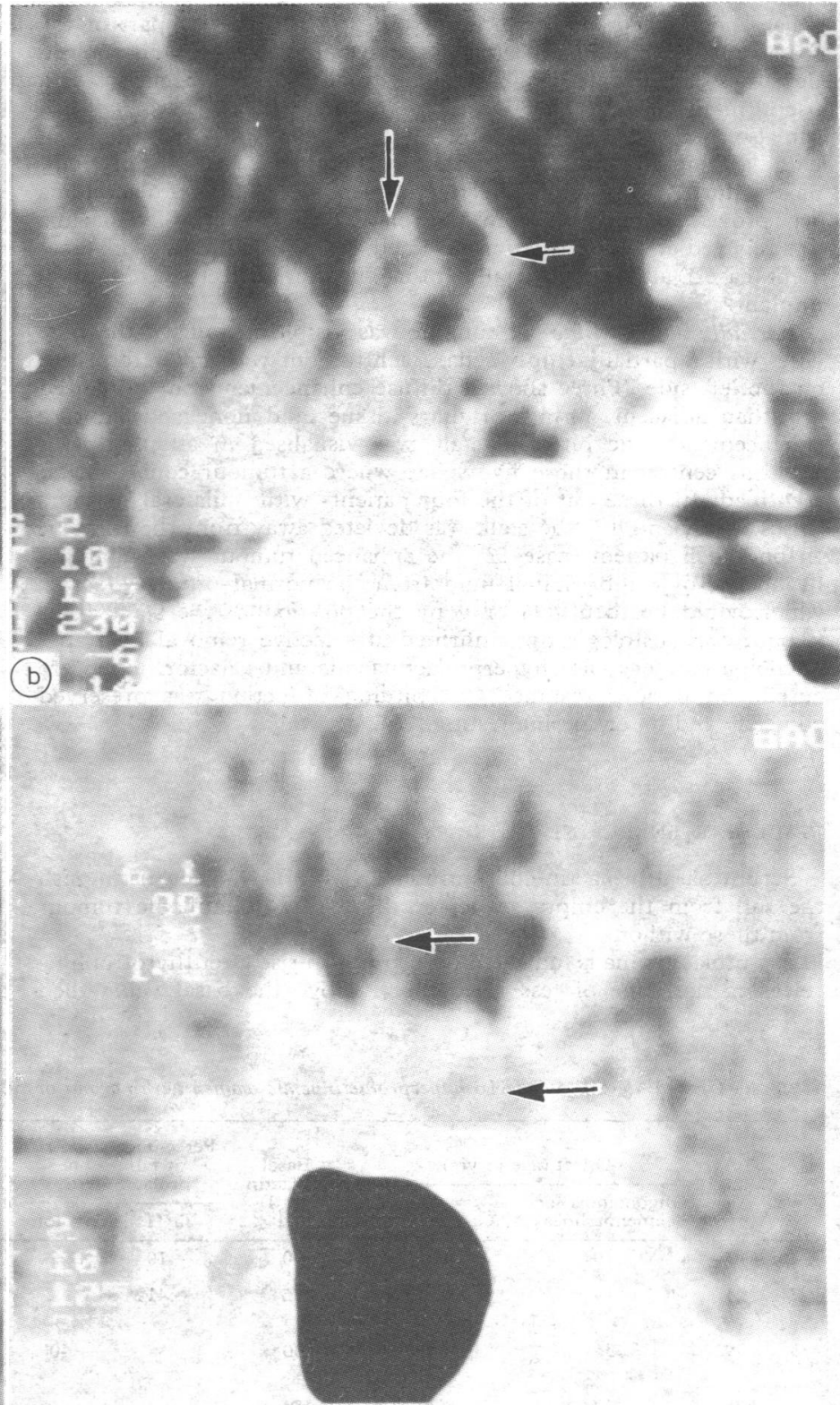

FIG 2-Case 4. CT scan showing left-sided tumour (arrow) with deviation of stalk (arrow) away from tumour: this deviation was used to identify normal pituitary.

placed in the fossa; if undisplaced it abutted the dorsum sellae in a mid-clinoid position, as had been noted by Smaltino and colleagues. ${ }^{7}$ We found coronal cuts especially useful in delineating stalk shift. In two patients the accuracy of tumour localisation by computed tomography was proved by needle or open biopsy at the time of definitive ablation of the tumour and in a third by the lowering of serum prolactin concentration by a selective yttrium-90 implant.

In all six cases where no differential enhancement could be identified in pituitary tissue the stalk appeared undisplaced, and in these cases it would appear that either no tumour existed or that the tumour enhanced to the same degree as the normal pituitary tissue but was too small to displace the stalk. Our series also showed that the instrument was able both to define the degree of empty sella and to delineate the precise position of the extension of cerebrospinal fluid into the fossa, which in 
some patients was lateralised (fig 1) or could be seen as a narrow cleft. A tumour in the remaining tissue in a partially empty sella could also be defined, allowing us to identify four tumours in partially empty sellae and in one patient (case 12) to remove the tumour selectively, leaving the normal pituitary tissue and function undisturbed. Other features of value that were clearly visualised included bony erosion, lateral and suprasellar spread of the tumour (case 7), and exclusion of an aneurysm eroding into the pituitary fossa. Such precision has now rendered the expensive and distressing technique of air encephalography and metrizamide contrast procedures practically obsolete in our practice.

Computed tomography enables the clinician to assess more accurately the possible likelihood of dangerous pituitary expansion in any future pregnancy-for instance, one patient (case 7) had a normal-sized fossa radiologically but showed a $4 \mathrm{~mm}$ suprasellar extension that could have produced visual impairment had the patient become pregnant. The clinician can now assess the feasibility of selective tumour removal or ablation and obtain a non-invasive follow-up.

Although it appeared that the tests using metoclopramide and thyrotrophin-releasing hormone correctly identified tumour in most cases, the number of false-positives in those without visible tumours tended to negate their value. A tumour may however, become visible in those sellae with no visible microadenoma at present, and so a definite answer on the validity of dynamic tests must be qualified and indeed may never be resolved, for indefinite follow-up would be required. Certainly hormonal studies could not clearly identify full from empty sella.

The fourth-generation CT scanners are thus a major advance in the understanding of disease of the sella in those with hyperprolactinaemia be it from tumourous causes or other conditions.

We thank Mr D Thomas of the National Hospital, Queen Square, who selectively removed the tumour in case 12 , for allowing publication of this case, and we acknowledge the technical skill of Miss Linda M Banks, who conducted the CT examinations. We thank Sandoz Products Ltd for supporting the endocrine studies and the Bernard Sunley Trust for the generous donation of the Siemens Somatom II to the Royal Postgraduate Medical School. MCW is in receipt of a Medical Research Council Training Fellowship.

\section{References}

${ }^{1}$ Gemzell C, Wang CF. Outcome of pregnancy in women with pituitary adenoma. Fertil Steril 1979;31:363-72.

${ }^{2}$ Nillius SJ, Bergh T, Larson SG. Pituitary tumours and pregnancy. In: Derome PJ, Jedynak CP, Peilon F, eds. Pituitary adenomas: biology, physiopathology and treatment. France: Asclepios, 1980:103-11.

${ }^{3}$ Bamberger-Bozo CH. Microadenomas and CT scan. In: Derome PJ, Jedynak CP, Peilon F, eds. Pituitary adenomas: biology, physiopathology and treatment. France: Asclepios, 1980:179-88.

${ }^{4}$ MacErlean DP, Doyle FH. The pituitary fossa in Cushing's syndrome; a retrospective analysis of 93 patients. Br $\mathcal{F}$ Radiol 1976;49:820-6.

${ }^{5}$ Harsoulis P, Marshall JC, Kuku SF, Burke CW, London DR, Fraser TR. Combined test for assessment of anterior pituitary function. $\mathrm{Br} \mathrm{Med} \mathcal{F}$ 1973;iv:326-9.

${ }^{6}$ Kelly WF, Mashiter K, Doyle FH, Banks LM, Joplin GF. Treatment of prolactin-secreting pituitary tumours in young women by needle implantation of radioactive yttrium. $Q \mathcal{F}$ Med $1978 ; 47: 473-93$.

7 Smaltino F, Bernini FP, Muras I. Computed tomography for diagnosis of empty sella associated with enhancing pituitary microadenoma. $\mathcal{F}$ Comput Ass Tomogr 1980;4:592-9.

(Accepted 11 August 1982)

\section{SHORT REPORTS}

\section{Oesophageal resection in patients with oesophageal speech}

In the past five years we have seen two patients with total laryngectomy and "oesophageal speech" who developed diseases of the oesophagus requiring oesophageal resection. Both sustained no further loss of voice despite removal of the lower oesophagus. This suggests that oesophageal speech is generated predominantly in the upper oesophagus and that a functioning lower oesophageal sphincter is not necessary for its production.

\section{Case reports}

Case 1-A 52-year-old woman presented to the otolaryngology department in 1970 with hoarseness. Laryngoscopy and biopsy showed squamous carcinoma of the larynx. This was irradiated but the tumour persisted, and total laryngectomy with a tracheostomy and left-sided cervical lymph-node dissection was performed in 1971. She learnt oesophageal speech and remained well until 1977, when she was admitted to the thoracic surgical unit with dysphagia of one month's duration, weight loss, and substernal pain. Barium swallow showed a tumour of the lower third of the oesophagus, which was confirmed by oesophagoscopy. At operation a squamous tumour was removed by oesophagogastrectomy, with oesophagogastric anastomosis just below the aortic arch. On the first postoperative day she had a weak oesophageal voice, but this rapidly became stronger. She made an uncomplicated recovery and was discharged on the 19th day after operation, by which time her voice was indistinguishable from her preoperative voice, as judged by herself, her family, and attending doctors. Her speech remained good until her death two years later from metastatic carcinoma.

Case 2-A 50-year-old man presented to the otolaryngology department in 1970 with a one-year history of hoarseness and pain on coughing. Laryngoscopy and biopsy showed squamous carcinoma of the right vocal cord with extension to the second tracheal ring. Radiotherapy was ineffective in controlling the tumour, and emergency tracheostomy was required. Total laryngectomy and right cervical lymph-node dissection were subsequently performed. Excision was complete and recovery excellent with the development of good oesophageal speech. Nine years later he developed dysphagia. Barium swallow showed a hiatus hernia with a severe reflux stricture, confirmed by oesophagoscopy. Oesophagogastrectomy with oesophagogastric anastomosis below the aortic arch was performed. The next day his oesophageal speech was present, but weak. He made an uncomplicated recovery, and on discharge his oesophageal speech was unchanged in strength and character from its preoperative state; he noted, however, that he had to "gulp" more air to produce the same number of words. His oesophageal speech was excellent at his last visit in 1982, and he had had no further dysphagia.

\section{Comment}

After total laryngectomy patients are dependent on oesophageal function if they are to regain some form of speech. ${ }^{12}$ Subsequent development of oesophageal disease therefore raises the possibility that they will again lose the voice that has been so painstakingly acquired. A Nissen fundoplication for hiatus hernia has been reported to cause no impairment of voice, ${ }^{4}$ but the effects of oesophagectomy have not previously been described.

The results after operation in our patients indicate that neither the development of an obstruction in the oesophagus (tumour in one case, stricture in the other) nor the removal of the lower oesophagus had any long-term adverse effect on the voice. The means by which oesophageal speech is produced are still not fully understood but must require a reservoir and a vibrating mechanism. ${ }^{5}$ The findings in these patients suggest that the lower oesophagus and lower sphincter are not essential for either of these functions. Hence patients with oesophageal speech can be reassured that distal oesophagectomy will not cause loss of voice for a second time, though the effects of proximal oesophagectomy in such patients are still unknown.

${ }^{1}$ Snidecor JC, Curry ET. How effectively can the laryngectomee speak ? Laryngoscope 1960;70:62-7.

${ }^{2}$ Robe EY, Moore P, Andrews AH, Holinger PH. A study of the role of certain factors in the development of speech after laryngectomy. 1. Type of operation. 2. Site of pseudoglottis. 3. Co-ordination of speech with respiration. Laryngoscope 1956;66:173-86,382-401,481-99.

${ }^{3}$ Simpson IC, Smith JCS, Gordon MT. Laryngectomy: the influence of muscle reconstruction on the mechanism of oesophageal voice production. F Laryngol Otol 1972;86:961-90.

$\underline{\underline{m}}$

(2) 